\title{
Biomethane potential of industrial paper wastes and investigation of the methanogenic communities involved
}

\author{
Andreas Walter ${ }^{1,2^{*}}$, Sandra Silberberger ${ }^{1}$, Marina Fernández-Delgado Juárez ${ }^{1}$, Heribert Insam ${ }^{1}$ \\ and Ingrid H. Franke-Whittle ${ }^{1}$
}

\begin{abstract}
Background: Cellulose-containing waste products from the agricultural or industrial sector are potentially one of the largest sources of renewable energy on earth. In this study, the biomethane potential (BMP) of two types of industrial paper wastes, wood and pulp residues (WR and PR, respectively), were evaluated under both mesophilic and thermophilic conditions, and various pretreatment methods were applied in the attempt to increase the methane potential during anaerobic digestion. The methanogenic community composition was investigated with denaturing gradient gel electrophoresis (DGGE) and the ANAEROCHIP microarray, and dominant methanogens were quantitated using quantitative PCR.

Results: All pretreatments investigated in this study with the exception of the alkaline pretreatment of PR were found to increase the BMP of two paper industry wastes. However, the low recalcitrance level of the PR resulted in the pretreatments being less effective in increasing BMP when compared with those for WR. These results were supported by the physico-chemical data. A combined application of ultrasound and enzymatic pretreatment was found to be the best strategy for increasing methane yields. The retention time of substrates in the reactors strongly influenced the BMP of wastes subjected to the different pretreatments. In sludges from both paper wastes subjected to the various pretreatments, mixotrophic Methanosarcina species were found to dominate the community, accompanied by a consortium of hydrogenotrophic genera.

Conclusions: Pretreating industrial paper wastes could be a potentially viable option for increasing the overall degradation efficiency and decreasing reactor retention time for the digestion of complex organic matter such as lignocellulose or hemicellulose. This would help reduce the environmental burden generated from paper production. Although there were minor differences in the methanogenic communities depending on the temperature of anaerobic digestion, there was little effect of substrate and pretreatment type on the community composition. Thus, methanogen community dynamics would not seem to be an appropriate indicator regarding BMP in the AD processes investigated.
\end{abstract}

Keywords: Pulp and paper residues, Anaerobic digestion, Pretreatments, ANAEROCHIP microarray, qPCR, Methanogens, Methanosarcina

\section{Background}

Due to the incessant and escalating demand and consumption of paper-based products, the pulp and paper market is one of the world's fastest growing industries,

\footnotetext{
*Correspondence: a.walter@uibk.ac.at

${ }^{1}$ Institut für Mikrobiologie, Universität Innsbruck, Technikerstraße 25d,

6020 Innsbruck, Austria

Full list of author information is available at the end of the article
}

expected to increase by $60 \%$ between 2012 and 2020 [1]. Paper, as we know it today, was developed in China almost 2000 years ago [2], and there are five basic steps in the process of pulp and paper production. In a preliminary debarking step, bark is removed and the wood is converted into smaller wooden chips. Pulping (mechanical or chemical) follows debarking, and in this step the majority of lignin and hemicellulose is removed from 
wooden chips. The brown pulp is then bleached such that the desired colour (dictated by product standards) is obtained. Bleaching agents are removed in a subsequent washing step [3], and the pulp slurry generated is subsequently dried on a paper machine and sheets of paper are produced.

The pulp and paper industry is, however, a major consumer of natural resources (wood and water) as well as energy (fossil fuels and electricity), and typically produces significant amounts of environmentally damaging pollutants [2]. Because of increasing legislative pressures forcing the industry to 'clean-up', as well as advances in process technologies, the industry has managed to reduce its impact on the environment during recent decades by $80-90 \%$ [2].

The anaerobic digestion (AD) of residues arising from the production of paper has the potential to concurrently counteract environmental and economic issues. In a cascade of steps including hydrolysis, acidogenesis, acetogenesis and methanogenesis, a consortium of bacteria and archaea convert organic matter into biogas (50-80\% methane), an energy carrier [4]. However, in the case of pulp and paper wastes, the inherent recalcitrant nature of the lignocellulosic materials can result in a problematic bioconversion to biogas. The $\mathrm{AD}$ of such materials is limited by the rate of hydrolysis, because the primary biodegradable polymer, cellulose, is shielded by both lignin and hemicellulose [5]. This complex structure dictates that the degradation process occurs slowly, and thus long hydrolytic retention times and reactor volumes are required for the large-scale $\mathrm{AD}$ of such wastes, resulting in higher capital costs [6].

In order to increase the overall degradation efficiency and decrease reactor retention time for the digestion of complex organic matter such as lignocellulose or hemicellulose, different pretreatment methods can be applied $[4,7]$. Different physical, chemical, physico-chemical and biological pretreatments have been used in various studies to break plant cell wall structures, making the organic materials more susceptible to hydrolysis, and thus aiding the $\mathrm{AD}$ process [8]. However, no studies are known to the authors where different pretreatment strategies have been applied to solid paper wastes and their impact on the biomethane potential (BMP) have been analysed. Nothing is known about the influence of the various pretreatments on methanogenic communities in such wastes.

The aim of this study was to determine the BMP of two industrial paper wastes. In order to assess the BMP, two different temperatures for $\mathrm{AD}$ were tested $\left(37\right.$ and $\left.55^{\circ} \mathrm{C}\right)$, as were six different pretreatment methods. Pretreatment methods included an autoclave pretreatment, an ultrasound pretreatment, an alkali $(\mathrm{NaOH})$ pretreatment, the use of enzymes (cellulases, hemicellulases, ligninases), a combination of enzymes with ultrasound pretreatment, and the addition of commercially available hydrolytic microorganisms.

It is hypothesised that waste-derived methane yields could be increased by various pretreatments. A second hypothesis was that the pretreatments would exert little influence on the methanogenic communities in the resulting anaerobic sludges.

In order to investigate the effects of the different pretreatments and $\mathrm{AD}$ temperatures on the methanogenic communities involved, denaturing gradient gel electrophoresis (DGGE) and ANAEROCHIP microarrays combined with quantitative PCR (qPCR) were applied.

\section{Results and discussion}

\section{Physico-chemical parameter analysis}

Physico-chemical properties of the inoculum cattle slurry (CS) and industrial paper wastes pulp residues (PR) and wood residues (WR) are shown in Table 1 . The same properties for the sludges obtained after 23 days of $\mathrm{AD}$ of the waste materials subjected to various pretreatments are shown in Table 2.

As expected, there was a reduction in the total solids (TS) and volatile solids (VS) in all samples after AD. The lowest TS and VS values were found in sludges in which the wastes were pretreated with a combination of enzymes and ultrasound. Lower TS and VS levels were also revealed after AD at $55^{\circ} \mathrm{C}$ (WR55 and PR55) compared with after $\mathrm{AD}$ at $37^{\circ} \mathrm{C}$. Together, these results indicate a higher organic carbon mineralisation into methane under thermophilic conditions.

The highest $\mathrm{pH}$ values were found in the sludges from AD at $55{ }^{\circ} \mathrm{C}$ (WR55 and PR55), while significantly lower values were observed in the sludges where wastes were pretreated with ultrasound and enzymes (WR37us+en, PS37us+en). Higher pH values under thermophilic conditions have been observed previously and explained by

Table 1 Physico-chemical characteristics of inoculum and paper wastes

\begin{tabular}{llll}
\hline & Cattle slurry & Wood residues & Pulp residues \\
\hline TS (\% FW w/v) & $8.23(0.18)$ & $36.5(0.06)$ & $41.0(0.08)$ \\
VS (\% FW w/v) & $5.82(0.13)$ & $35.3(0.07)$ & $23.3(0.06)$ \\
$\mathrm{pH}$ & $7.95(0.02)$ & $2.31(0.02)$ & $8.55(0.02)$ \\
$\mathrm{NH}_{4}-\mathrm{N}\left(\mathrm{mg} \mathrm{L}^{-1}\right)$ & $1600(159)$ & $\mathrm{nm}$ & $\mathrm{nm}$ \\
$\begin{array}{c}\text { Cellulose content (\%) } \\
\text { Hemicellulose con- }\end{array}$ & $\mathrm{nm}$ & 44.6 & 46.3 \\
$\quad$ tent (\%) & 1.20 & 4.50 \\
Lignin content (\%) & $\mathrm{nm}$ & 11.4 & 0.03 \\
\hline
\end{tabular}

$n=3$; standard error is given in brackets

TS total solids, FW fresh weight, VS volatile solids, $\mathrm{nm}$ not measured 
Table 2 Physico-chemical parameters of sludges measured after 23 days of anaerobic digestion

\begin{tabular}{|c|c|c|c|c|c|c|c|}
\hline Name & TS (\% FW w/v) & VS (\% FW w/v) & $\mathrm{pH}$ & TAN (mg L $\left.\mathrm{L}^{-1}\right)$ & Acetate (mM) & Propionate (mM) & $\mathrm{CH}_{4}\left(\mathrm{Nml} \mathrm{gVS}^{-1}\right)$ \\
\hline WR37 & $7.74(0.13) \mathrm{a}$ & $5.44(0.08) a$ & $7.81(0.02) \mathrm{a}$ & $1533(44.1) a b$ & $0.13(0.13)$ & nd & $116(7.51) \mathrm{a}$ \\
\hline WR37au & $7.34(0.07) \mathrm{ac}$ & $5.27(0.05) \mathrm{a}$ & $8.16(0.02) b$ & $1867(136) b$ & nd & nd & 165 (2.08) ab \\
\hline WR37us & $6.35(0.07) b$ & $4.53(0.05) b$ & $8.04(0.01) b$ & $1250(50.0) \mathrm{a}$ & $0.04(0.04)$ & nd & 195 (4.42) ab \\
\hline WR37al & $6.10(0.08) \mathrm{bd}$ & $4.17(0.07) \mathrm{d}$ & $8.11(0.01) b$ & 1350 (132) a & $0.57(0.46)$ & $0.25(0.25)$ & 139 (12.4) ab \\
\hline WR37mo & $6.95(0.14) c$ & $4.86(0.06) c$ & $7.82(0.04) \mathrm{a}$ & 1367 (183) ab & nd & nd & 137 (36.2) ac \\
\hline WR37en & $6.09(0.18) \mathrm{bd}$ & $4.20(0.08) d$ & $7.79(0.06) \mathrm{a}$ & $1433(44.1) a b$ & $0.10(0.05)$ & nd & 203 (23.3) bc \\
\hline WR37us+en & $5.63(0.04) d$ & $3.99(0.03) d$ & $7.64(0.01) c$ & $1417(60.1) a b$ & nd & nd & $222(5.04) b$ \\
\hline PR37 & $7.87(0.02) a$ & $4.74(0.03) \mathrm{a}$ & $7.82(0.02) a$ & $1800(50.0) \mathrm{a}$ & $0.12(0.07)$ & nd & $323(4.96) \mathrm{a}$ \\
\hline PR37au & $7.61(0.26) \mathrm{a}$ & $4.67(0.21) \mathrm{a}$ & $8.15(0.02) b$ & 1683 (174) ab & nd & nd & 331 (8.53) a \\
\hline PR37us & $7.25(0.25) \mathrm{a}$ & $4.62(0.13) a$ & $8.00(0.01) c$ & 1650 (104) ab & $0.03(0.03)$ & nd & $400(7.30) b$ \\
\hline PR37al & $6.06(0.16) b c$ & $3.57(0.13) b$ & $8.06(0.02) c$ & 1567 (267) ab & $0.49(0.24)$ & $1.17(0.62)$ & $202(17.8) c$ \\
\hline PR37mo & $7.17(0.07) \mathrm{a}$ & $4.23(0.05) \mathrm{ac}$ & $7.79(0.01) \mathrm{a}$ & $1567(44.1) a b$ & $0.07(0.04)$ & nd & $324(5.73) a$ \\
\hline PR37en & $6.38(0.05) b$ & $3.81(0.02) b c$ & $7.66(0.01) d$ & $1500(50.0) a b$ & $0.03(0.03)$ & nd & 351 (2.79) a \\
\hline PR37us+en & $5.54(0.03) c$ & $3.41(0.03) b$ & $7.59(0.02) \mathrm{e}$ & 1067 (16.7) b & nd & nd & 408 (8.37) b \\
\hline WR55 & $3.81(0.30)$ & $2.48(0.22)$ & $8.30(0.03)$ & $1550(76.4)$ & nd & 1.65 (1.30) & $171(6.01)$ \\
\hline PR55 & $2.91(0.02)$ & $1.77(0.05)$ & $8.31(0.04)$ & $1567(44.1)$ & $1.11(0.35)$ & $6.75(0.66)$ & $368(7.89)$ \\
\hline
\end{tabular}

$n=3$; standard error is given in brackets. Different letters (a-e) indicate significant differences between pretreatments $(p<0.05)$ for each waste material according to the Tukey HSD test

TS total solids, VS volatile solids, $F W$ fresh weigh, $n d$ not detected, $W R$ wood residues, $P R$ pulp residues, $37 \mathrm{AD}$ at $37^{\circ} \mathrm{C}, 55 \mathrm{AD}$ at $55^{\circ} \mathrm{C}$, au autoclave pretreatment, $u s$ ultrasound pretreatment, al alkaline pretreatment, mo pretreatment with commercial microorganism mixture, en enzyme pretreatment

the bioenergetics balance and alkalinity differences [9, $10]$.

Total ammonia nitrogen (TAN) concentrations increased during $\mathrm{AD}$ as a result of urea and protein hydrolysis, but were not found to be inhibitory. No clear differences were observed between mesophilically and thermophilically treated samples. Results are in line with the findings of Moset et al. [10].

Acetate levels were low $(<0.57 \mathrm{mM})$ in all mesophilic sludges. Under thermophilic conditions however, a higher acetate concentration $(1.11 \mathrm{mM})$ was found in the PR, although no acetate was detected in WR. Propionate was detected only in the mesophilic sludges treated under alkaline conditions (al), while it was detected at higher levels in both thermophilic sludges investigated. Similar observations were reported by Moset et al. [10] and Kim et al. [11]. Nonetheless, all acetate and propionate concentrations measured were found to be far below the critical values of 45 and $15 \mathrm{mM}$, respectively [12]. Levels of butyrate, isobutyrate, valerate and isovalerate, suggested to be good indicators for reactor instability [13], were also found to be under the detection limit of $0.5 \mathrm{mM}$ (results not shown). The low concentrations of volatile fatty acids (VFA) in the samples after $\mathrm{AD}$ indicate an efficient transformation of metabolites into $\mathrm{CH}_{4}$ through a wellbalanced consortium of bacteria and methanogens during the $\mathrm{AD}$ process.

\section{Evaluation of pretreatment efficiency to increase methane yield}

The degradation of complex polymers is known to be a bottleneck in AD processes [7]. Hemicellulases and cellulases produced by the bacterial digester community are capable of the breakdown of hemicellulolytic polymers into mono-, di-, and oligosaccharides. Nevertheless, the degradation efficiency is low. Hemicellulose consists mostly of heteroxylans (hardwood hemicellulose) or glucomannans (softwood hemicellulose), connected through diferulic or isodityrosine bridges and forming an insoluble network, in which cellulose microfibrils are imbedded [14]. Thus, increasing the hydrolysis rate of these complex polymers by some form of pretreatment is crucial in engineered $A D$ processes in order to improve the biomass-conversion efficiency and decrease the hydraulic retention time [4].

In this study, pretreatment efficiency was evaluated by comparing the daily and accumulated $\mathrm{CH}_{4}$ yield of both pretreated and non-pretreated paper wastes during a 23-day AD process. Non-pretreated WR and PR produced $116( \pm 7.51)$ and $323( \pm 4.96) \mathrm{ml} \mathrm{CH}_{4} \mathrm{~g}^{-1} \mathrm{VS}$ at $37^{\circ} \mathrm{C}$, and $171( \pm 6.01)$ and $368( \pm 7.89) \mathrm{ml} \mathrm{CH}_{4} \mathrm{~g}^{-1} \mathrm{VS}$ at $55^{\circ} \mathrm{C}$, respectively (Table 2 and Fig. 1a). The lower $\mathrm{CH}_{4}$ yields from WR compared with PR may be attributed to the higher lignin content (11.4\%, Table 1$)$. Results are in line with yields from paper wastes published by Raposo et al. [15], where yields of $120-320 \mathrm{ml} \mathrm{CH}_{4} \mathrm{~g}^{-1} \mathrm{VS}$ for pulp and 84-369 $\mathrm{ml} \mathrm{CH}_{4} \mathrm{~g}^{-1} \mathrm{VS}$ for paper waste were 

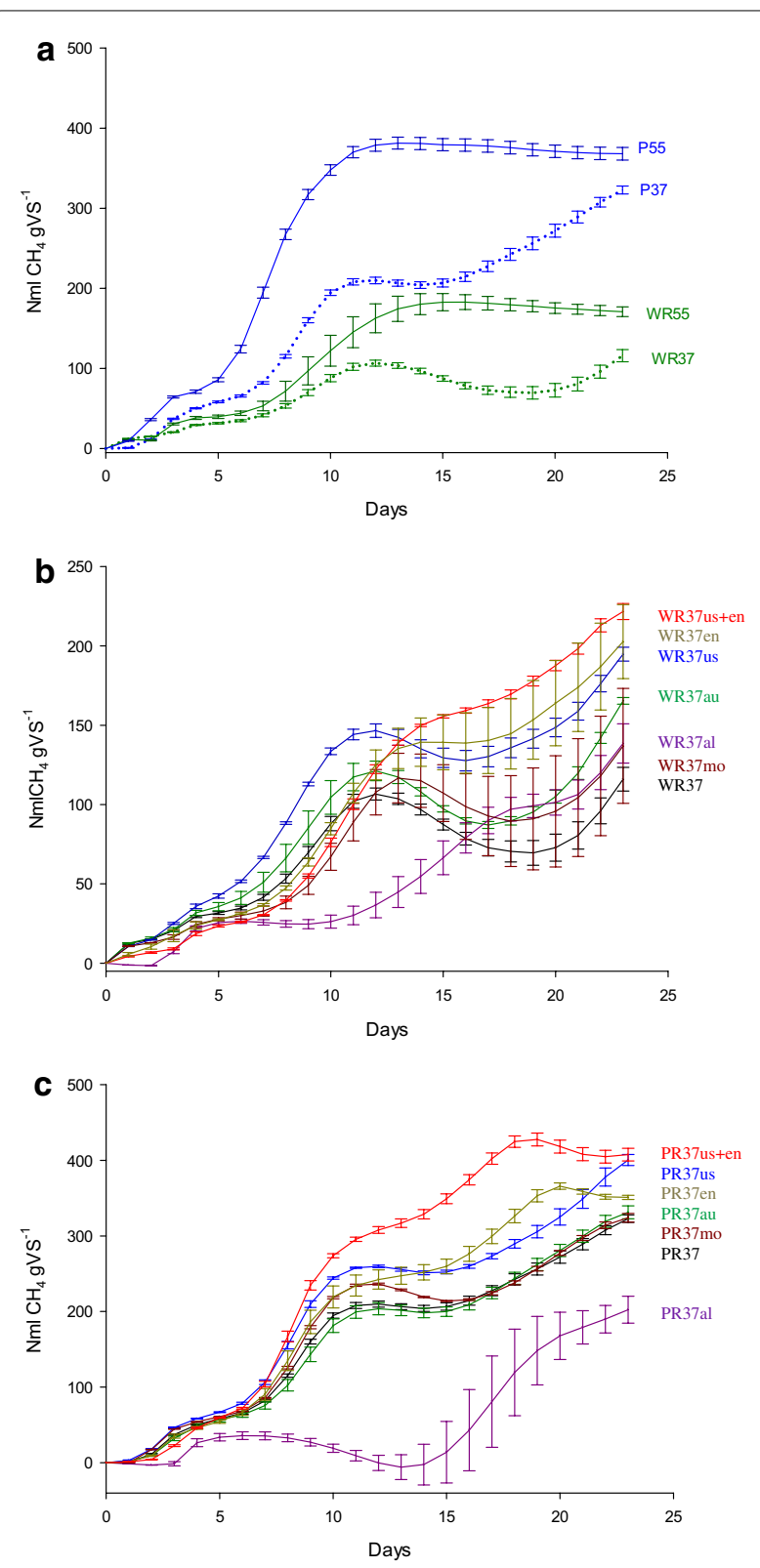

Fig. 1 a Accumulated methane production from non-pretreated waste residues (WR) and pulp residues (PR) at $37^{\circ} \mathrm{C}$ and at $55^{\circ} \mathrm{C}$. Average values $(n=3)$ are plotted and error bars indicate standard error. b Accumulated methane production at $37^{\circ} \mathrm{C}$ from pretreated wood residues (WR). au autoclave pretreatment, us ultrasound pretreatment, al alkaline pretreatment, mo commercial microorganism mixture pretreatment, en enzyme pretreatment. Average values $(n=3)$ are plotted and error bars indicate standard error. c Accumulated methane production at $37^{\circ} \mathrm{C}$ from pretreated pulp residues (PR). Average values $(n=3)$ are plotted and error bars indicate standard error

reported. Temperature did not affect methane production ( $p=0.17)$, but yields obtained from PR were significantly higher than result obtained from WR according to the Mann-Whitney tests $(\mathrm{p}<0.01)$.
All pretreatments of WR resulted in $\mathrm{CH}_{4}$ yield increases (Table 2; Fig. 1b). In contrast, there was a significant decrease in $\mathrm{CH}_{4}$ yield (37 \%) after alkaline pretreatment of PR, and only after pretreatment with ultrasound and a combination of ultrasound and enzymes were significant increases in $\mathrm{CH}_{4}$ production from PR obtained. The lower BMP resulting from alkaline treatment is most likely due to a negative effect on the microbial community imposed by sodium ions, dissociated from $\mathrm{NaOH}$. $\mathrm{Na}$ ions at low concentrations are essential for microorganisms, probably because of their role in the formation of adenosine triphosphate or the oxidation of NADH [16]. Moderate $\mathrm{Na}$ concentrations have been found to stimulate microbial growth and to be antagonistic to ammonia inhibition $[17,18]$. Excessive Na amounts, however, can decrease and inhibit growth [19]. Soto et al. [20] and Liu and Boone [21] detected toxic effects of $\mathrm{Na}$ on VFA and lignocellulose degrading bacteria as well as on methanogens at concentrations of 14 and $27.7 \mathrm{~g} \mathrm{~L}^{-1}$, respectively. According to the literature, the level at which $\mathrm{Na}$ exerts a toxic effect varies, probably due to methodological and environmental differences and microbial adaptation to particular conditions. It would seem that the $10 \mathrm{~g} \mathrm{~L}^{-1} \mathrm{NaOH}$ used in this study caused a negative effect on the AD of PR, which most likely absorbed the $\mathrm{NaOH}$. Such an effect was not observed for the WR. A detoxification of the PR waste prior to AD by removal of the $\mathrm{NaOH}$ possibly would have resulted in improved methane yields. According to the literature, other alkaline agents such as $\mathrm{KOH}$ or lime could be used for pretreatment. However, according to Zhu et al. [22] and Penaud et al. [23], the use of $\mathrm{NaOH}$ revealed the highest pretreatment efficiency of all tested bases.

Acetate levels were higher in sludges of both WR and PR subjected to alkaline pretreatment, when compared to all other treatments (Table 2) and propionate was exclusively detected in both wastes which underwent alkaline pretreatment, with average concentrations up to $1.17 \mathrm{mM}$ (PR37al). These findings indicate a negative effect on both propionate and acetate utilising microorganisms, and are in line with the results of Soto et al. [20].

Of the two physical disintegration methods applied in this study, ultrasound was found to be the most efficient in raising the BMP. A $68 \%$ increase in $\mathrm{CH}_{4}$ yield for WR and a $24 \%$ increase in methane yield for PR were found after 23 days of AD, when compared to non-pretreated wastes. Positive effects of ultrasound pretreatment have been published before. In a study of Khanal et al. [24], a digester receiving sonicated waste activated sludge removed 11-39 \% more soluble COD than the digester receiving non-sonicated sludge. Also, Muller et al. [25] reported an improvement of gas production by $17 \%$, with a $6.2 \%$ increase in total solids removal in mesophilic $38 \mathrm{~L}$ reactors with 15 days of retention times. 
However, disadvantages with this pretreatment approach exist, due to the high amount of energy required and technical issues in large-scale applications. The autoclaving pretreatments were found to be less effective, resulting in a $43 \% \mathrm{CH}_{4}$ increase for the WR, and a negligible $3 \%$ increase for PR.

The effectiveness of amendment with microorganisms was lower for both WR and PR compared with other methods (except for alkaline treatment of PR). There was an $18 \%$ increase in $\mathrm{CH}_{4}$ production in WR37mo, while there was no increase in $\mathrm{CH}_{4}$ yield for PR37mo. It is possible that the 23 days of $\mathrm{AD}$ used in the experiment was not long enough to allow an efficient adaption of the amended microorganisms to the reactor conditions. The application of commercially available enzymes as a pretreatment approach resulted in a significant increase in $\mathrm{CH}_{4}$ production for WR $(+75 \%)$, but in only a small increase for PR $\left(+9 \% \mathrm{CH}_{4}\right)$. Most likely, the enzymes were able to aid in the degradation of the lignocellulosic WR, but were not as useful with the pulp waste which had lower lignin content. Mayhew et al. [26] were able to increase the biogas production by $10 \%$, when pretreating waste activated sludge with enzymes at $42{ }^{\circ} \mathrm{C}$ for 2 days. In the study of Davidsson et al. [27], methane production was increased by $60 \%$ during pilot-scale trials, by introducing prepared enzyme solution to a pre-hydrolysation contact chamber with an HRT of $4 \mathrm{~h}$.

As stated by Parawira [28], pretreating pulp and paper residues with microorganisms or cell-free enzymes can be effective if the appropriate microorganisms or enzymes are applied and operating conditions, dosage and enzyme-to-waste ratio are optimal. The applications of both microorganisms and cell-free enzymes have advantages and disadvantages. Cell-free enzymes, on the one hand, are active under a wide range of environmental conditions and remain active even when conditions quickly change [28]. Enzymes also tolerate the presence of different microorganisms and possible inhibitors of microbial metabolism. In contrast, the implementation of vital microorganisms is potentially more dynamic and efficient, due to the ability of microorganisms to directly produce enzymes as well as their physiological flexibility and motility. However, in this study, the bacterial consortium selected was found to be incapable of increasing the degradation efficiency of PR. Results indicated that the application or pretreatment conditions used were either inadequate or inappropriate.

The combined application of ultrasound and enzymes as a pretreatment method was found to be the most suitable approach for both wastes. Significantly higher $\mathrm{CH}_{4}$ yields of +91 and $+26 \%$ were revealed for WR37us+en and PR37us+en, respectively, compared to non-pretreated wastes after 23 days of AD. Pretreatment with ultrasound waves most likely increased the accessible surface area and decreased the polymerisation degree of the cellulose. As a result, enzymes could attack the disintegrated fibres more efficiently, due to the enlarged surface area.

The residence time of substrates in the AD reactors was found to strongly influence the BMP of paper wastes subjected to the different pretreatments (Figs. 1b, 1c). After 7 days of $\mathrm{AD}, \mathrm{WR}$ subjected to an autoclaving pretreatment $\left(+23 \% \mathrm{CH}_{4}\right)$ or ultrasound pretreatment $(+61 \%$ $\mathrm{CH}_{4}$ ) yielded the highest amounts of $\mathrm{CH}_{4}$. Compared to non-pretreated WR, enzymes alone $\left(-12 \% \mathrm{CH}_{4}\right)$ or in combination with ultrasound pretreatment $\left(-27 \% \mathrm{CH}_{4}\right)$ revealed lower $\mathrm{CH}_{4}$ yields. In contrast, after 14 days of $\mathrm{AD}$, the increase in $\mathrm{CH}_{4}$ yield for autoclaving (+12\%), ultrasound $(+40 \%)$ and enzyme pretreatments $(+44 \%)$ were lower than that of the combined ultrasound and enzyme pretreatment ( $+55 \%)$. Pretreatment with ultrasound alone, and in combination with enzymes, were found to be the most suitable methods for enhancing $\mathrm{CH}_{4}$ yields of $\mathrm{PR}$ under both short and long reactor residence times. Increases of 30 and $27 \%$ for the ultrasound and ultrasound/enzyme treatments, respectively, were reported after 7 days of $\mathrm{AD}$. After 14 days, $\mathrm{CH}_{4}$ yields increased in the combined pretreatments compared to non-pretreated PR $\left(+61 \% \mathrm{CH}_{4}\right)$, but decreased in ultrasound pretreatments $\left(+23 \% \mathrm{CH}_{4}\right)$. These findings illustrate the importance of striking a balance between shortened AD times and efficient substrate degradation in biogas plant operation.

Methane production curves (Fig. $1 \mathrm{a}-\mathrm{c}$ ) revealed the existence of multiple phases under mesophilic conditions. Such diauxic phenomena are frequently observed in batch experiments when high concentrations of homologous substrates are processed [29]. Under such conditions, the substrate which supports the highest growth rate is utilised initially, while the consumption of poorer substrates remains repressed. Diauxie has also been observed in reactors digesting multi-component agro-wastes [30] and cow manure with food waste or leaves/straw [31]. Kübler and Schertler [32] observed an initial inhibition of the hydrolysis of cellulosic material when dissolved and easy-to-degrade monomers such as sugars were present. The polymeric structural carbohydrates were degraded subsequently in a second hydrolysation phase. We suppose the same phenomena appeared in this study and resulted in the biphasic or multiphasic $\mathrm{CH}_{4}$ production curves. Also, short-time decreases in methane yields can be observed in several of the graphs showing cumulative methane yield under mesophilic conditions. This effect may be attributed to metabolic adjustments in-between phases and an improved degradation of the $\mathrm{CS}$ at that point in time. Thus, when 
subtracting the negative control CS from the treatments, it appeared that a decrease in the cumulated methane amount occurred.

\section{Methanogen community composition and stability}

DNA from CS and sludges after AD at $37{ }^{\circ} \mathrm{C}$ were subjected to DGGE and bands were analysed in a fingerprint cluster analysis (Fig. 2a). The undigested CS was found to group distinctly from all samples, while PR and WR subjected to different pretreatments showed more than $75 \%$ similarity to each other. Digestates did not, however, group together according to waste origin or pretreatment type; rather, a large cluster containing all samples except the non-pretreated CS and the WR subjected to autoclaving was observed. Samples in this cluster shared more than $80 \%$ similarity with each other.

By comparing anaerobic sludges treated at mesophilic and thermophilic temperatures, a clear effect on the archaeal communities was detected after 23 days of $\mathrm{AD}$ (Fig. 2b). The CS not subjected to AD grouped distinctly from both the 37 and $55^{\circ} \mathrm{C}$ digestates, but more closely with the $37{ }^{\circ} \mathrm{C}$ digestates (62.5\% similarity). The WR and PR paper wastes were found to have no significant influence on the fingerprinting patterns obtained after AD.

To investigate the methanogen communities in the digestates of WR37, PR37, WR55, PR55 and CS, the $16 S$ rRNA gene-based ANAEROCHIP microarray was applied. In all samples, signal-to-noise ratios (SNRs) $>2$ were found for probes targeting the family Methanobacteriaceae (family to which genus Methanobrevibacter belongs) as well as the genera Methanosarcina, Methanobrevibacter, Methanoculleus and Methanosphaera (results not shown). Additionally, probes targeting an uncultured clone [33] hybridised with DNA from the CS and sludges after AD at thermophilic conditions (WR55 and PR55). SNRs exceeding the threshold level of two were included in a PCA (Fig. 3). The two axes represent $73.3 \%$ of the variance, with the first and second axis representing 45.3 and $28.0 \%$ of the variance, respectively. Different samples are represented by circles, squares and polygons, the oligonucleotide probes of the ANAEROCHIP microarrays by vectors. Particular probes can be seen to be more important in discriminating the samples. The lengths of the arrows indicate the significance for sample differentiation, and arrows point in the direction of samples with above average signal. Similar vector direction of probes signifies high covariance, indicating probes were detected mutually in the samples.

The PCA loading plot clustering supports the findings of DGGE fingerprinting, whereby the undigested CS clustered distinctly to the samples after 23 days of AD. Additionally, wastes treated under mesophilic conditions were distinct from wastes digested under thermophilic conditions.
qPCR was conducted to quantify methanogens (with the exception of the uncultured clone for which no positive control was available) detected with the ANAEROCHIP microarray (Table 3). In all samples investigated, Methanosarcina was the most dominant genus. Despite the non-significant difference, it is worth mentioning the increase in the gene copy number (GCN) of Methanosarcina found in WR and PR samples digested under mesophilic temperatures $\left(2.39 \times 10^{8}\right.$ and $2.03 \times 10^{8}$, respectively) when compared to the inoculum CS $\left(5.80 \times 10^{7}\right)$. In contrast, there was a slight, but significant decrease in the GCN of Methanosarcina in the WR55 and PR55 samples $\left(2.48 \times 10^{7}\right.$ and $4.75 \times 10^{7}$, respectively) compared to inoculum CS.

Dominance of Methanosarcina has been frequently reported in the literature for reactors treating manures $[10,34,35]$ and reactors experiencing instable conditions during start-up procedures $[33,36]$. Methanosarcina is capable of metabolising a broad spectrum of substrates, including $\mathrm{H}_{2}, \mathrm{CO}_{2}$, methanol, methylamine and acetate [37]. Being capable of both acetoclastic and hydrogenotrophic methanogenesis (i.e. mixotrophic methanogenesis), Methanosarcina is more flexible to changing substrate conditions and the presence of inhibitors [38]. It is characterised by high growth rates (i.e. doubling times in the order of 1-1.2 days) and a tolerance to sudden changes in $\mathrm{pH}$ of around $0.8-1.0$ units. In comparison, other methanogens have doubling times of 4-6 days and tend to be affected by $\mathrm{pH}$ changes of 0.5 units or even less $[39,40]$. The ability of Methanosarcina to acclimatise and adapt more effective to modified environmental conditions and to dominate the methanogenic community in our study was therefore not surprising.

Methanobrevibacter was found to be the second most prevalent methanogenic genus in all samples, with GCNs of $>10^{7}$. This strictly hydrogenotrophic genus is considered to be the dominant methanogen in the rumen environment, representing up to $61.6 \%$ of the archaeal community [41] due to its high growth rate and ability to competitively utilise $\mathrm{H}_{2}$ and $\mathrm{CO}_{2}$ [42]. Consequently, the detection of high Methanobrevibacter numbers in the CS samples of this study was not unexpected and has been confirmed in other studies [33, 43, 44]. GCNs of the genus in samples digested under thermophilic conditions (PR55 and WR55) were significantly lower than in the CS control (Table 3).

In contrast, a significant increase of Methanoculleus in GCN was detected after AD under thermophilic conditions for both waste residues. GCNs of the hydrogenotrophic methanogen Methanosphaera were found to remain stable during mesophilic AD of WR and PR wastes $\left(\sim 2 \times 10^{6}\right)$, but decreased approximately fivefold in samples after AD under thermophilic conditions 
a
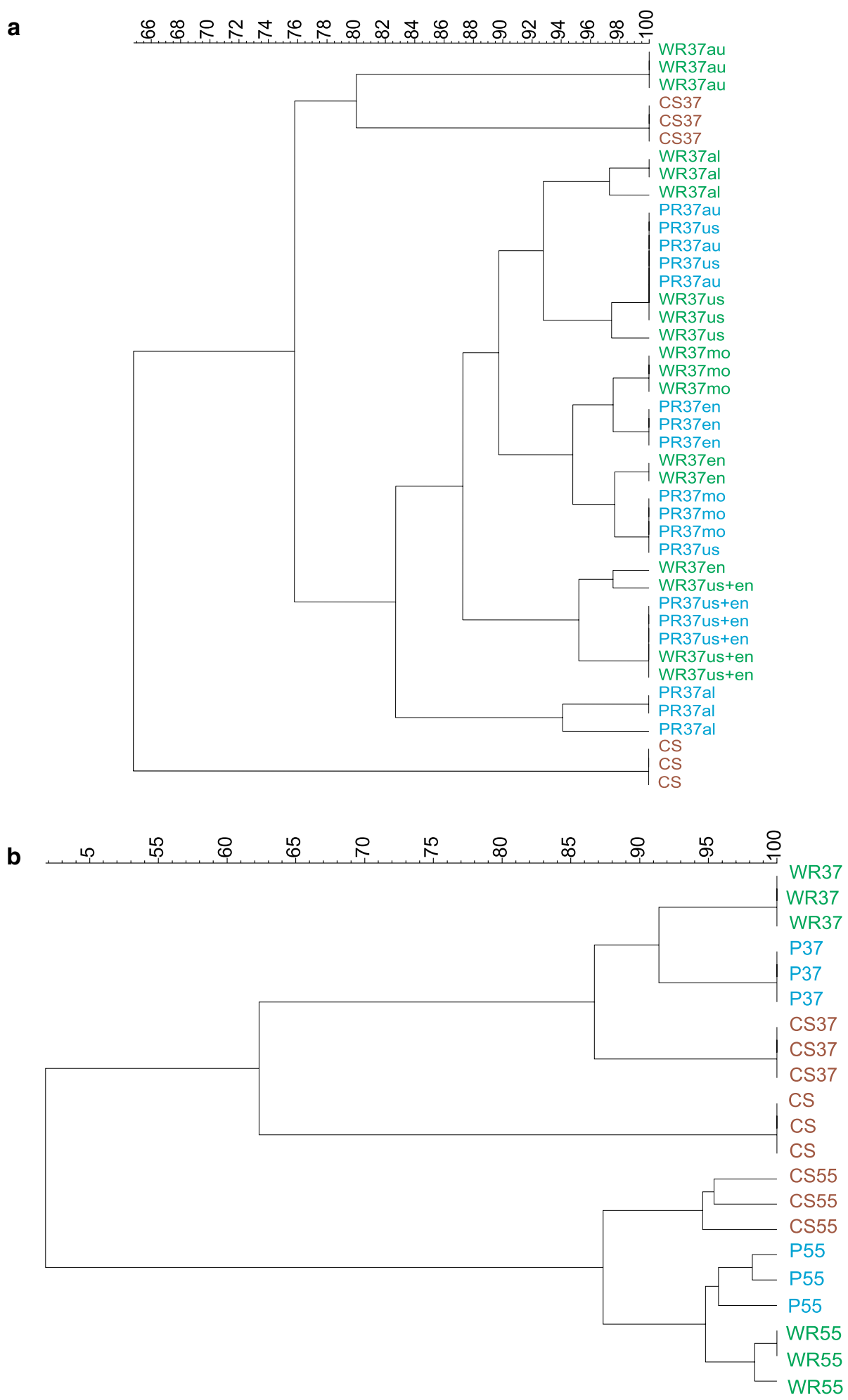

Fig. 2 a Cluster analysis of DGGE fingerprints based on the PCR of archaeal 16S rRNA genes extracted from undigested cattle slurry (CS) and sludges after anaerobic digestion at $37^{\circ} \mathrm{C}$. WR Wood residues, PR Pulp residues, 37 Anaerobic digestion at $37^{\circ} \mathrm{C}$, au autoclave pretreatment, us ultrasound pretreatment, al alkaline pretreatment, mo commercial microorganism mixture addition, en enzyme pretreatment. $\mathbf{b}$ Cluster analysis of DGGE fingerprints based on the PCR of archaeal 165 rRNA genes extracted from cattle slurry and sludges after anaerobic digestion at 37 and $55^{\circ} \mathrm{C}$. CS cattle slurry, WR wood residues, $P R$ pulp residues, 37 anaerobic digestion at $37^{\circ} \mathrm{C}, 55$ anaerobic digestion at $55^{\circ} \mathrm{C}$ 


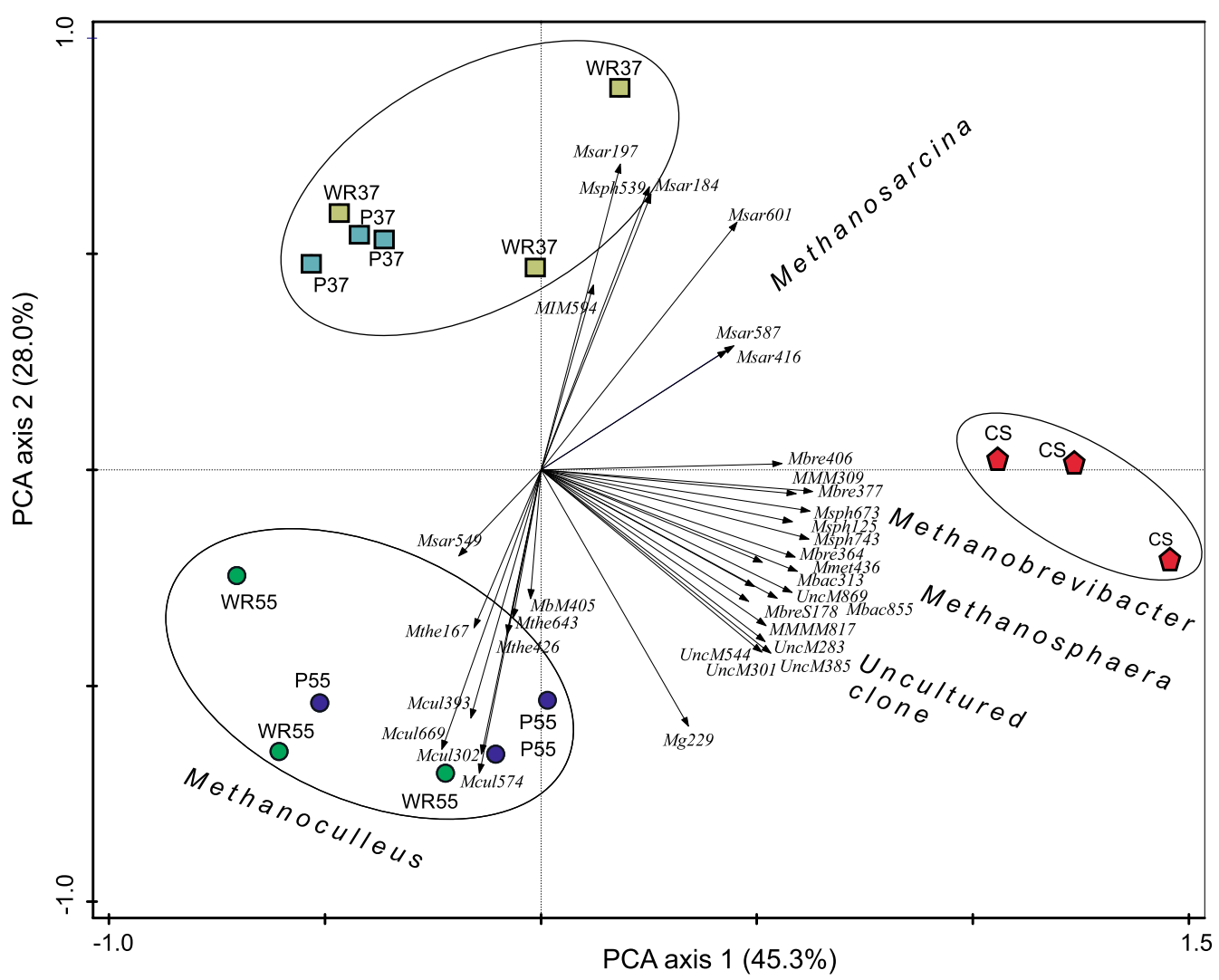

Fig. 3 Loading plot obtained by principal component analysis, depicting the clustering of cattle slurry and the digestates WR37, PR37, WR55 and PR55. The vectors represent the different probes of the ANAEROCHIP microarray. CS cattle slurry, WR wood residues, PR pulp residues, 37 anaerobic digestion at $37^{\circ} \mathrm{C}, 55$ anaerobic digestion at $55^{\circ} \mathrm{C}$

Table 3 Primers, standard curve parameters and number of gene copies $\mathrm{ml}^{-1}$ sample of the investigated genera

\begin{tabular}{llllc}
\hline & Methanosarcina & Methanobrevibacter & Methanoculleus & Methanosphaera \\
\hline F primer & 240F (CCTATCAGGTAG & 210F (TTTCGCCTAA & 298F (GGAGCAAGAGC & 594F (TAAGTCTTTGG \\
& TAGTGGGTGTAAT) & GGATGGGTCT) & CCGGAGT) & TGAAGCTT) \\
R primer & 589R (CCCGGAGGACT & 367R (CGATTTCTCAC & 586R (CCAAGAGACTTA & 747R (GTTACTCACCG \\
& GACCAAA) & ATTGCGGAG) & ACAACCCA) & TCAAGAT) \\
$R^{2}$ value & 0.9999 & 0.9993 & 0.9999 & 0.9994 \\
Slope & -4.53 & -3.958 & -4.679 & -4.358 \\
Intersept & 38.913 & 35.106 & 43.209 & 38.283 \\
Efficiency & 0.66 & 0.79 & 0.64 & 0.70 \\
CS & $5.80 \mathrm{E}+07(3.24 \mathrm{E}+06) \mathrm{a}$ & $2.99 \mathrm{E}+07(3.98 \mathrm{E}+06) \mathrm{a}$ & $1.98 \mathrm{E}+06(8.95 \mathrm{E}+05) \mathrm{a}$ & $2.31 \mathrm{E}+06(2.90 \mathrm{E}+05) \mathrm{a}$ \\
WR37 & $2.39 \mathrm{E}+08(2.98 \mathrm{E}+07) \mathrm{ab}$ & $2.13 \mathrm{E}+07(3.29 \mathrm{E}+06) \mathrm{ab}$ & $4.63 \mathrm{E}+06(9.85 \mathrm{E}+05) \mathrm{ab}$ & $2.95 \mathrm{E}+06(7.85 \mathrm{E}+05) \mathrm{ab}$ \\
WR55 & $2.48 \mathrm{E}+07(4.53 \mathrm{E}+06) \mathrm{b}$ & $1.21 \mathrm{E}+07(1.90 \mathrm{E}+06) \mathrm{b}$ & $9.51 \mathrm{E}+06(1.74 \mathrm{E}+06) \mathrm{b}$ & $7.66 \mathrm{E}+05(1.98 \mathrm{E}+05) \mathrm{b}$ \\
PR37 & $2.03 \mathrm{E}+08(1.71 \mathrm{E}+07) \mathrm{a}$ & $2.62 \mathrm{E}+07(2.55 \mathrm{E}+06) \mathrm{a}$ & $1.04 \mathrm{E}+07(1.63 \mathrm{E}+06) \mathrm{a}$ & $2.91 \mathrm{E}+06(6.09 \mathrm{E}+05) \mathrm{a}$ \\
PR55 & $4.75 \mathrm{E}+07(3.28 \mathrm{E}+06) \mathrm{b}$ & $1.21 \mathrm{E}+07(1.28 \mathrm{E}+06) \mathrm{b}$ & $1.95 \mathrm{E}+07(6.18 \mathrm{E}+06) \mathrm{b}$ & $7.83 \mathrm{E}+05(1.51 \mathrm{E}+04) \mathrm{b}$ \\
WR37us+en & $1.67 \mathrm{E}+08(2.06 \mathrm{E}+07) \mathrm{b}$ & $2.09 \mathrm{E}+07(3.56 \mathrm{E}+06) \mathrm{ab}$ & $7.23 \mathrm{E}+06(5.46 \mathrm{E}+05) \mathrm{ab}$ & $2.11 \mathrm{E}+06(1.23 \mathrm{E}+05) \mathrm{ab}$ \\
PR37us+en & $1.54 \mathrm{E}+08(1.85 \mathrm{E}+07) \mathrm{ab}$ & $3.40 \mathrm{E}+07(4.48 \mathrm{E}+06) \mathrm{a}$ & $1.12 \mathrm{E}+07(2.98 \mathrm{E}+06) \mathrm{a}$ & $7.15 \mathrm{E}+05(9.79 \mathrm{E}+04) \mathrm{a}$ \\
\hline
\end{tabular}

$n=6$; standard error is given in brackets. Different letters indicate significant differences between pretreatments $(p<0.05)$ according to the Tukey HSD test CS cattle slurry, WR wood residues, $P R$ pulp residues, 37 anaerobic digestion at $37^{\circ} \mathrm{C}, 55$ anaerobic digestion at $55^{\circ} \mathrm{C}$, us ultrasound pretreatment, en enzyme pretreatment 
(Table 3). This is most likely because no thermophilic species are known to exist in the genus Methanosphaera [37].

Due to the relatively low level of variation in numbers of the dominant methanogens investigated using qPCR, it would appear that the quantity of these methanogens in samples cannot be used as an appropriate indicator for $\mathrm{BMP}$ in the $\mathrm{AD}$ processes investigated. The role of acetate oxidisers in this study, with respect to the generation of $\mathrm{CH}_{4}$, is unclear. Westerholm et al. [45] found Methanosarcina and syntrophic acetate-oxidising bacteria in high abundance in mesophilic reactors, fed with a mixture of cattle manure and silage. This indicated that the genus acted as an important hydrogenotrophic, and not acetoclastic methanogen in the reactors investigated. Thus, it would appear that this mixotrophic methanogen can act as a mediator of the whole acetate-oxidation process, as proposed previously [46].

\section{Conclusions}

This study has shown that all pretreatments investigated were found to considerably increase the methane yields from the WR. Pretreatment of the PR was found to be less effective in increasing BMP, due to its low recalcitrance. These results were supported by the physico-chemical data. The combined application of ultrasound with enzymes was the best possible pretreatment strategy for both PR and WR wastes. Chemical and biological pretreatments, more cost-effective approaches than ultrasound and enzymatic pretreatments [8], revealed differing results for the two wastes. Pretreatment with microorganisms and enzymes was found to be a suitable approach for WR, but less effective for PR. The application of $\mathrm{NaOH}$ was not effective at all, probably due to inhibition from the high sodium ion concentrations.

The retention time of substrates in the reactors strongly influenced the BMP of wastes subjected to the different pretreatments. This finding illustrates the importance of finding a balance between shortened retention times and efficient substrate degradation in biogas plant operation.

In all substrate-amended reactors, Methanosarcina was the dominating genus, accompanied by a consortium of hydrogenotrophs. However, relatively little variation in the numbers of the dominant methanogens were found in digested sludges of the wastes subjected to various pretreatments prior to $\mathrm{AD}$, using $\mathrm{qPCR}$. Thus, methanogen numbers would not seem to be an appropriate indicator regarding $\mathrm{BMP}$ in the $\mathrm{AD}$ processes investigated.

In conclusion, it would seem that the $\mathrm{AD}$ of pretreated pulp and paper wastes could be a potentially viable option for utilising and reducing the huge amounts of waste products generated from one of the world's biggest industries. This would help reduce the environmental burden generated from paper production. More research, however, is needed in order to further investigate the economical issues involved with pretreatment of the wastes.

\section{Methods}

\section{Paper wastes and inoculum source for $A D$}

The two pulp and paper wastes tested in this study were WR, produced in the mechanical and chemical pulping process and bleached PR, collected after screening, cleaning and washing of the pulp product. To decrease particle size to below $2 \mathrm{~mm}$, WR and PR were ground in a coffee grinder (CG100 140 W; De'Longhi-Kenwood, Hampshire, United Kingdom). Cellulose, hemicellulose and lignin contents in WR and PR were determined and calculated as described by Van Soest et al. [47]. CS collected from a farm in Innsbruck (Tyrol, Austria; $47^{\circ} 16^{\prime} 2^{\prime \prime} \mathrm{N}$, $11^{\circ} 23^{\prime} 34^{\prime \prime} \mathrm{E}$ ) was used as an inoculum for AD. CS was sieved with a 4-mm sieve and left over night at $37{ }^{\circ} \mathrm{C}$ to degas. Test materials and inoculum were stored in aliquots at $-20{ }^{\circ} \mathrm{C}$ until use. Substrate and inoculum characteristics are listed in Table 1.

\section{Pretreatment of paper wastes}

WR and PR were subjected to six different pretreatments. For thermal-high pressure extraction, residues were autoclaved (au) at $121{ }^{\circ} \mathrm{C}$ with 1 bar overpressure in a steam steriliser (Varioklav, HP Medizintechnik GmbH, Oberschleißheim, Germany) for $20 \mathrm{~min}$. An ultrasound (us) pretreatment was conducted by adding $50 \mathrm{ml}$ distilled water to $15.8 \mathrm{~g}$ WR and $23.5 \mathrm{~g}$ PR, and subjecting residues to ultrasound wave frequencies (Elmasonic $\mathrm{S} 100 \mathrm{H}$, Elma, Schmidbauer GmbH, Singen, Germany) at $37 \mathrm{kHz}$ and $600 \mathrm{~W}$ for $30 \mathrm{~min}$. For the alkaline pretreatment (al), 15.84 $\mathrm{g}$ WR and $23.5 \mathrm{~g}$ PR were submerged in $100 \mathrm{ml}$ of $1 \% \mathrm{NaOH}(\mathrm{w} / \mathrm{v})$. Flasks were incubated at room temperature for $24 \mathrm{~h}$, after which time the $\mathrm{NaOH}$-containing supernatant was carefully removed. An enzyme (en) pretreatment was conducted by adding $4.8 \mu \mathrm{l}$ of an enzyme mix containing equal amounts of cellulases, hemicellulases and ligninases (Novozymes, Franklinton, United States) to $15.84 \mathrm{~g}$ WR and $23.5 \mathrm{~g}$ PR suspended in 50 and $75 \mathrm{ml}$ of distilled water, respectively. After $\mathrm{pH}$ adjustment to six, flasks were incubated at $55^{\circ} \mathrm{C}$ with shaking $(125 \mathrm{rpm})$ for $24 \mathrm{~h}$. Thereafter, enzymes were inactivated by boiling pretreated residues for $15 \mathrm{~min}$. Additionally, a combination of an ultrasound and enzyme pretreatment (us+en) was conducted. Finally, $6 \times 10^{-4} \mathrm{~g}$ BGMax 3000 commercial microorganism mix (mo) obtained from Novozymes (Franklinton, United States) was added to reactor flasks directly prior to $\mathrm{AD}$, and additionally, on days 7 and 14. BGMax 3000 contains viable bacterial, fungal and yeast cultures [48]. 


\section{Determination of BMP}

To determine methane production from wastes at different temperatures and to compare the efficiency of the various pretreatments, a BMP test was performed in a batch-mode AMPTS II (Bioprocess Control, Lund, Sweden) for 23 days. Treatments were tested in triplicate in total reactor volumes of $400 \mathrm{ml}$. The inoculum-tosubstrate ratios (CS:WR and CS:PR) calculated with VS amounts were set to four. Non-pretreated WR and PR were digested under mesophilic $\left(37^{\circ} \mathrm{C}\right)$ and thermophilic $\left(55{ }^{\circ} \mathrm{C}\right)$ conditions. Statistical tests revealed no significant differences between both temperatures (see results and discussion section); thus, pretreated paper wastes were subjected to $\mathrm{AD}$ at $37^{\circ} \mathrm{C}$. Intermittent stirring, set at $112 \mathrm{rpm}$, was applied for 15 min daily to ensure adequate mixing in the reactors. Finally, the BMP from all reactors was calculated by subtracting the BMP measured in the control reactors which contained exclusively CS. An overview of all pretreated and nonpretreated paper wastes after 23 days of $\mathrm{AD}$ is presented in Table 2.

\section{Physico-chemical analyses}

Physical and chemical parameters of fresh CS, WR and $\mathrm{PR}$, as well as of digested sludges obtained after AD were measured. To determine TS, approximately $50 \mathrm{~g}$ of fresh sample was dried at $105{ }^{\circ} \mathrm{C}$ for $24 \mathrm{~h}$ and weighed after cooling in a desiccator. VS were calculated as the loss of weight after igniting $2 \mathrm{~g}$ of the oven-dried residue at $550{ }^{\circ} \mathrm{C}$ in a muffle furnace for $5 \mathrm{~h}$. To extract total ammonia nitrogen (TAN), $15 \mathrm{ml}$ of sample was mixed with $60 \mathrm{ml}$ of a $0.0125 \mathrm{M}$ calcium chloride solution and the mixture shaken at $150 \mathrm{rpm}$ at room temperature for $1 \mathrm{~h}$ prior to being filtered through a paper filter. TAN concentration was measured using the colorimetric tube test (Macherey-Nagel GmbH and Co. KG, Düren, Germany) according to the manufacturer's instructions. Free ammonia nitrogen (FAN) was calculated from TAN concentrations, as described in Calli et al. [49]. To determine $\mathrm{pH}$ of WR and PR, the residues were diluted 1:10 with distilled water and gently shaken at room temperature for 2 h. $\mathrm{pH}$ was measured with a portable multi-parameter meter Multi 340i (WTW, Weilheim, Germany). For highperformance liquid chromatography analyses, volatile fatty acids (VFAs) were extracted in dialysis tubing with $10 \mathrm{ml}$ distilled water. Sample containing bottles were shaken three times and stored at $4{ }^{\circ} \mathrm{C}$ overnight in order to reach a total equilibrium in the dialysate. Dialysate $(0.5 \mathrm{ml})$ was then transferred onto an Aminex HPX$87 \mathrm{H}$ column (Bio-Rad, Hercules, USA). A $5 \mathrm{mM} \mathrm{H}_{2} \mathrm{SO}_{4}$ mobile phase run at $0.7 \mathrm{ml} \mathrm{m^{-1 }}$ and a detection wavelength of $210 \mathrm{~nm}$ were used to detect VFAs present at concentrations $>0.5 \mathrm{mM}$.

\section{Microbiological analyses \\ DNA extraction}

DNA extraction from the CS and all digested samples was conducted using the NucleoSpin ${ }^{\circledR}$ Soil DNA isolation Kit (Macherey-Nagel GmbH and Co. KG, Düren, Germany) according to the manufacturer's instructions. Quality of extracted DNA was controlled with agarose gel electrophoresis. Extracts were stored at $-20{ }^{\circ} \mathrm{C}$ until use.

\section{Dgge}

DNA for DGGE analysis was amplified by the polymerase chain reaction (PCR). After an initial denaturation at $94{ }^{\circ} \mathrm{C}$ for $5 \mathrm{~min}, 33$ cycles of $94{ }^{\circ} \mathrm{C}$ for $1 \mathrm{~min}, 49{ }^{\circ} \mathrm{C}$ for $2 \mathrm{~min}$ and $72{ }^{\circ} \mathrm{C}$ for $2 \mathrm{~min}$ were performed. An elongation step at $72{ }^{\circ} \mathrm{C}$ for 15 min completed DNA amplification. Each PCR reaction contained $0.2 \mu \mathrm{M}$ of each primer

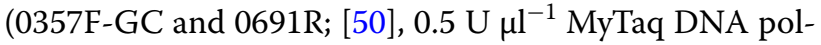
ymerase, $1 \mathrm{X}$ MyTaq reaction buffer, $0.4 \mathrm{mg} \mathrm{ml}^{-1}$ bovine serum albumin (BSA) and $1 \mathrm{X}$ enhancer (Peqlab, Germany). Finally, $1 \mu \mathrm{l}$ extracted DNA was added to $24 \mu \mathrm{l}$ of the PCR mastermix. PCR products were loaded into a $7-8 \%(\mathrm{w} / \mathrm{v})$ polyacrylamide gel with a denaturing gradient of $42-62 \%$ (100\% denaturant consists of $7 \mathrm{M}$ urea plus $40 \%$ formamide in $1 \mathrm{X}$ TAE buffer) and gels were run for $16 \mathrm{~h}$ at $100 \mathrm{~V}$ in $1 \mathrm{X}$ TAE buffer $(\mathrm{pH} 7.4)$ at a constant temperature of $60{ }^{\circ} \mathrm{C}$. Gels were stained with silver nitrate in an automated gel stainer (Amersham Pharmacia Biotech, Germany).

16S rRNA gene amplification and ANAEROCHIP hybridisation DNA extracts of CS, WR37, PR37, WR55 and PR55 were subjected to PCR using the $16 S$ rRNA gene specific primers $109 \mathrm{~F}$ and 934r [51]. PCR amplification, fluorescence labelling of target DNA, hybridisation, scanning and analysis of arrays were conducted as described by FrankeWhittle et al. [52]. SNR signals with intensities $\geq 2$ were treated as positive signals.

\section{Real-time quantitative PCR}

To quantify methanogens detected using the ANAEROCHIP microarray, CS and the digested sludges from WR37, PR37, WR55, PR55, WR37us+en and PR37us+en were subjected to qPCR with genus-specific primers for Methanosarcina, Methanobrevibacter, Methanoculleus and Methanosaeta. Primers, as well as important standard curve parameters (efficiency, slope, intercept and $R^{2}$ ) are presented in Table 3. qPCR was performed as described in Franke-Whittle et al. [52] by adding $2 \mu \mathrm{l}$ of template DNA to a reaction volume of $18 \mu \mathrm{l}$. After an initial denaturation step at $95{ }^{\circ} \mathrm{C}$ for $5 \mathrm{~min}$, thermal cycling comprised 45 cycles of $20 \mathrm{~s}$ at $95{ }^{\circ} \mathrm{C}, 20 \mathrm{~s}$ at $58-65{ }^{\circ} \mathrm{C}$ (annealing temperature) and $20 \mathrm{~s}$ at $72{ }^{\circ} \mathrm{C}$. 
Annealing temperatures of $64{ }^{\circ} \mathrm{C}$ for Methanosarcina, $59{ }^{\circ} \mathrm{C}$ for Methanobrevibacter, $65{ }^{\circ} \mathrm{C}$ for Methanoculleus and $61{ }^{\circ} \mathrm{C}$ for Methanosphaera were used. In order to check for primer dimer formation and product specificity, thermal cycling was completed with a melting analysis $\left(65-95^{\circ} \mathrm{C}\right.$, ramp $\left.0.5^{\circ} \mathrm{C} \mathrm{min}^{-1}\right)$. Standard curves were constructed with PCR amplified $16 S$ rDNA from pure cultures of Methanosarcina barkeri, Methanobrevibacter smithii, Methanoculleus (Clone F_2FA36; [53] and Methanosphaera stadtmanae, as described in Franke-Whittle et al. [54] and Goberna et al. [33]. All standards and samples were run in duplicate.

\section{Statistical analyses}

The differences in $\mathrm{CH}_{4}$ production regarding both temperature $\left(37\right.$ and $55{ }^{\circ} \mathrm{C}$ ) and paper wastes type (WR and $\mathrm{PR})$ were tested by non-parametric tests for pair-wise comparisons between different residues and temperature using the Mann-Whitney $U$ test $(\mathrm{p}<0.05)$, since data were not normally distributed.

To test the effects of the pretreatments (au, us, al, en, mo, us+en) on physico-chemical parameters and $\mathrm{CH}_{4}$ production on each of the paper wastes at $37{ }^{\circ} \mathrm{C}$, data were subjected to a one-way ANOVA.

Methanogen quantification data (qPCR) were analysed by one-way ANOVA. The normality and the variance homogeneity of the data were tested prior to ANOVA. Data were transformed when they did not resemble a normal distribution. Significant differences in the main effects were analysed by paired comparisons with the Tukey HSD (honestly significant difference) as a post hoc test $(\mathrm{p}<0.05)$. All statistical analyses were performed using the Statistica software program v9.

Comparison of archaeal DGGE patterns was conducted using the GelCompar II software package (Applied Maths, Belgium). DGGE bands were normalised using the reference position defined by the molecular-weight marker in order to align the bands for proper comparison. Cluster analysis was performed using Ochiai correlation coefficients and the Ward clustering algorithm. The programme settings were at $1 \%$ optimisation and $1 \%$ position tolerance.

PCA of SNRs from microarray data was conducted using CANOCO 5 [55].

\footnotetext{
Abbreviations

AD: anaerobic digestion; Al: alkaline pretreatment; Au: autoclave pretreatment; BMP: biomethane potential; CS: cattle slurry; DGGE: denaturing gradient gel electrophoresis; En: enzyme pretreatment; FAN: free ammonia nitrogen; FW: fresh weight; GCN: gene copy numbers; Mo: commercial microorganism mixture addition; Nd: not detected; Nm: not measured; PR: pulp residues; qPCR: quantitative PCR; TAN: total ammonia nitrogen; TS: total solids; Us: ultrasound pretreatment; VFA: volatile fatty acids; VS: volatile solids; WR: wood residues; 37 : $\mathrm{AD}$ at $37^{\circ} \mathrm{C} ; 55$ : $\mathrm{AD}$ at $55^{\circ} \mathrm{C}$.
}

\section{Authors' contributions}

AW helped in the design of experiments, performed qPCR studies and drafted the manuscript. SS performed physico-chemical parameter analysis, pretreatment experiments and BMP tests, and molecular analyses. MFDJ performed the statistical analysis. HI participated in the design of this study, helped coordinate the project and revised the manuscript. IFW designed and conceived this work and coordinated and helped draft the manuscript. All authors read and approved the final manuscript.

\section{Author details}

${ }^{1}$ Institut für Mikrobiologie, Universität Innsbruck, Technikerstraße 25d, 6020 Innsbruck, Austria. ${ }^{2}$ Hochschule Hamm-Lippstadt, Biotechnologie, Marker Allee 76-78, 59063 Hamm, Germany.

\section{Acknowledgements}

The project was funded by the Austrian Science Fund (FWF; P20001-B03). We would like to thank the Müller Abfallprojekte GmbH and EMOCell GmbH for providing the paper wastes. We would further like to thank the four anonymous reviewers for their constructive comments on this manuscript.

\section{Competing interests}

The authors declare that they have no competing interests.

Received: 20 October 2015 Accepted: 8 January 2016

Published online: 26 January 2016

\section{References}

1. Szyplinska P.CEO 360 Degree Perspective on the Global Pulp and Paper Water and Wastewater Treatment Market. Frost \& Sullivan's Environmental Research and Consulting. 2013. http://www.frost.com/sublib/displayreport.do?id=M8DB-01-00-00-00.

2. Thompson G, Swain J, Kay M, Forster CF. The treatment of pulp and paper mill effluent: a review. Bioresour Technol. 2001;77:275-86.

3. Ali M, Sreekrishnan TR. Aquatic toxicity from pulp and paper mill effluents - a review. Adv Environ Res. 2001;5:175-96.

4. Meyer T, Edwards EA. Anaerobic digestion of pulp and paper mill wastewater and sludge. Water Res. 2014;65:321-49.

5. Taherzadeh MJ, Karimi K. Acid-based hydrolysis processes for ethanol from lignocellulosic materials: a review. Bio Res. 2007;2:472-99.

6. Adney WS, Rivard CJ, Ming SA, Himmel ME. Anaerobic digestion of lignocellulosic biomass and waste. Cellulase and related enzymes. Appl Biochem Biotechnol. 1991;30:165-83.

7. Elliott A, Mahmood T. Pretreatment technologies for advancing anaerobic digestion of pulp and paper biotreatment residues. Water Res. 2007:41:4273-86.

8. Taherzadeh MJ, Karimi K. Pretreatment of lignocellulosic wastes to improve ethanol and biogas production: a review. Int J Mol Sci. 2008:9:1621-51.

9. Labatut RA, Angenent LT, Scott NR. Conventional mesophilic vs. thermophilic anaerobic digestion: a trade-off between performance and stability? Water Res. 2014;53:249-58.

10. Moset V, Poulsen M, Wahid R, Højberg O, Møller HB. Mesophilic versus thermophilic anaerobic digestion of cattle manure: methane productivity and microbial ecology. Microb Biotechnol. 2015:8(5):787-800.

11. Kim M, Ahn YH, Speece RE. Comparative process stability and efficiency of anaerobic digestion; mesophilic vs. thermophilic. Water Res. 2002;36:4369-85.

12. Nielsen $H B$, Uellendahl H, Ahring BK. Regulation and optimization of the biogas process: propionate as a key parameter. Biomass Bioenerg. 2007;31:820-30.

13. Nielsen HB, Mladenovska Z, Westermann P, Ahring BK. Comparison of two-stage thermophilic $\left(68^{\circ} \mathrm{C} / 55^{\circ} \mathrm{C}\right)$ anaerobic digestion with one-stage thermophilic $\left(55^{\circ} \mathrm{C}\right)$ digestion of cattle manure. Biotechnol Bioeng. 2004;86:291-300

14. Saha BC. Hemicellulose bioconversion. Ind Microbiol. Biotechnol. 2003;30:279-91. 
15. Raposo F, Rubia MAD, Fernandez-Cegri V, Borja R. Anaerobic digestion of solid organic substrates in batch mode: an overview relating to methane yields and experimental procedures. Renew Sustain Energy Rev. 2011;16:861-77.

16. Feijoo G, Soto M, Mendez R, Lema JM. Sodium inhibition in the anaerobic digestion process: antagonism and adaptation phenomena. Enz Microbiol Tech. 1995;17:180-8.

17. Chen Y, Cheng JJ, Creamer KS. Inhibition of anaerobic digestion process: a review. Bioresour Technol. 2008;99:4044-64.

18. Hendriksen HV, Ahring BK. Effects of ammonia on growth and morphology of thermophilic hydrogen-oxidizing methanogenic bacteria. FEMS Microb Ecol. 1991;85:241-6.

19. Soto M, Mendez R, Lema JM. Methanogenic and non-methanogenic activity tests: theoretical basis and experimental setup. Water Res. 1993;27:1361-76.

20. Soto M, Mendez R, Lema JM. Sodium inhibition and sulphate reduction in the anaerobic treatment of mussel processing wastewaters. J Chem Tech Biotechnol. 1993;58:1-7.

21. Liu Y, Boone DR. Effects of salinity on methanogenic decomposition. Bioresour Technol. 1991;35:271-3.

22. Zhu J, Wan C, Li Y. Enhanced solid-state anaerobic digestion of corn stover by alkaline pretreatment. Bioresour Technol. 2010;101:7523-8.

23. Penaud V, Delgenés JP, Moletta R. Thermo-chemical pretreatment of a microbial biomass: influence of sodium hydroxide addition on solubilization and anaerobic bio degrability. Enzyme Microb Technol. 1999;25:258-63.

24. Khanal SK, Isik H, Sung S, van Leeuwen JH. Ultrasound conditioning of waste activated sludge for enhanced aerobic digestion. In: Proceedings of the IWA Specialized Conference on Sustainable Sludge Management: State-of-the-Art, Challenges and Perspectives, Moscow; 2006: 441-448.

25. Muller C, Abu-Orf M, Blumenschein C, Novak J. The impact of ultrasound energy on mesophilic anaerobic digestion. In: WEF Proceedings of the Residuals and Biosolids Management Conference, Covington; 2005.

26. Mayhew M, Le M, Brade C, Harrison, D. The united utilities 'enzymic hydrolysis process' - validation of phased digestion at full-scale to enhance pathogen removal. In: WEF Proceedings of the Residuals and Biosolids Conference, Baltimore; 2003.

27. Davidsson A, Wawrzynczyk J, Norrlow O, Cour La, Jansen J. Strategies for enzyme dosing to enhance anaerobic digestion of sewage sludge. J Residuals Sci Technol. 2007;4:1-7.

28. Parawira W. Enzyme research and applications in biotechnological intensification of biogas production. Crit Rev Biotechnol. 2012;32:172-86.

29. Egli T, Lendenmann U, Snozzi M. Kinetics of microbial growth with mixtures of carbon sources. Antonie van Leeuwenhoek. 1993;63:289-98.

30. Misi SN, Froster CF. Batch co-digestion of multi-component agro-wastes. Bioresour Technol. 2001;80:19-28.

31. Ashekuzzaman SM, Poulsen TG. Optimizing feed composition for improved methane yield during anaerobic digestion of cow manure based waste mixtures. Bioresour Technol. 2011;102:2213-8.

32. Kübler H, Schertler $\mathrm{C}$. Three-phase anaerobic digestion of organic wastes. Wat Sci Tech. 1994;30:367-74.

33. Goberna M, Gadermaier M, García C, Wett B, Insam H. Adaptation of methanogenic communities to the co-fermentation of cattle excreta and olive mill wastes at $37^{\circ} \mathrm{C}$ and $55^{\circ} \mathrm{C}$. Appl Environ Microbiol. 2010;76:6564-71.

34. Karakashev D, Bastone D, Angelidaki I. Influence of environmental conditions on methanogenic compositions in anaerobic biogas reactors. Appl Environ Microbiol. 2005;71:331-8.

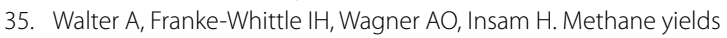
and methanogenic community changes during co-fermentation of cattle slurry with empty fruit bunches of oil palm. Bioresour Technol. 2015;175:619-23.

36. Demirel B, Scherer P. The roles of acetotrophic and hydrogenotrophic methanogens during anaerobic conversion biomass to methane: a review. Rev Environ Sci Biotechnol. 2008;7:173-90.

37. Dworkin M, Falkow S, Rosenberg E, Schleifer KH, Stackebrandt E. The prokaryotes. Archaea. Bacteria: Firmicutes, Actinomycetes, New York: Springer-Verlag; 2006. vol. 3.

38. Thauer RK, Kaster AK, Seedorf H, Buckel W, Hedderich R. Methanogenic archaea: ecologically relevant differences in energy conservation. Nat Rev Microbiol. 2008;6:579-91.

39. Conklin A, Stensel HD, Ferguson J. Growth kinetics and competition between Methanosarcina and Methanosaeta in mesophilic anaerobic digestion. Water Environ Res. 2006;78:486-96.

40. Shin SG, Zhou BW, Lee S, Kim W, Hwang S. Variations in methanogenic population structure under overloading of pre-acidified high-strength organic wastewaters. Process Biochem. 2011;46:1035-8.

41. Janssen PH, Kirs M. Structure of the archaeal community of the rumen. Appl Environ Microbiol. 2008;74:3619-25.

42. Kim M, Morrison M, Yu Z. Status of the phylogenetic diversity census of ruminal microbiomes. FEMS Microbiol Ecol. 2011;76:49-63.

43. Garcia JL, Patel BKC, Ollivier B. Taxonomic, phylogenetic, and ecological diversity of methanogenic Archaea. Anaerobe. 2000;6:205-26.

44. Souidi K, Mumme J, Mundt K, Nettmann E, Bergmann I, Linke B, Klocke M. Microbial diversity in a biogas-producing co-fermentation of maize silage and bovine manure. Agrartechnische Forsch. 2007;13:197-205.

45. Westerholm M, Leven L, Schnürer A. Bioaugmentation of syntrophic acetate-oxidizing culture in biogas reactors exposed to increasing levels of ammonia. Appl Environ Microbiol. 2012;78:7619-25.

46. Karakashev D, Batstone DJ, Trably E, Angelidaki I. Acetate oxidation is the dominant methanogenic pathway from acetate in the absence of Methanosaetaceae. Appl Environ Microbiol. 2006;72:5138-41.

47. Van Soest PJ, Robertson JB, Lewis BA. Methods for dietary fiber, neutral detergent fiber, and nonstarch polysaccharides in relation to animal nutrition. J Dairy Sci. 1991;74:3583-97.

48. Novozymes Biologicals Inc. SAFETY DATA SHEET. 2014. http://www. marylandbiochemical.com/wp-content/uploads/2015/05/7032711-BGMAX-3000.pdf.

49. Calli B, Mertoglu B, Inanc B, Yenigun O. Effects of high free ammonia concentrations on the performances of anaerobic bioreactors. Process Biochem. 2005:40:1285-92.

50. Watanabe T, Asakawa S, Nakamura A, Nagaoka K, Kimura M. DGGE method for analyzing 165 rDNA of methanogenic archaeal community in paddy field soil. FEMS Microbiol Lett. 2004;232:153-63.

51. Grosskopf R, Janssen PH, Liesack W. Diversity and structure of the methanogenic community in anoxic rice paddy soil microcosms as examined by cultivation and direct 165 rRNA gene sequence retrieval. Appl Environ Microbiol. 1998;64:960-9.

52. Franke-Whittle $\mathrm{IH}$, Walter $\mathrm{A}$, Ebner $\mathrm{C}$, Insam $\mathrm{H}$. Investigation into the effect of anaerobic digester acidity on methanogenic communities. Waste Manage. 2014;34:2080-9.

53. Goberna M, Insam H, Franke-Whittle $I H$. Effect of biowaste sludge maturation on the diversity of thermophilic bacteria and archaea in an anaerobic reactor. App Environ Microbiol. 2009;75:2566-72.

54. Franke-Whittle $I \mathrm{H}$, Goberna $M$, Insam $H$. Design and testing of real-time PCR primers for the quantification of Methanoculleus, Methanosarcina, Methanothermobacter and a group of uncultured methanogens. Can J Microbiol. 2009;55:611-6.

55. ter Braak CJF, S ${ }^{\vee}$ milauer P. Canoco reference manual and user's guide: software for ordination, version 5.0. Microcomputer Power, Ithaca. c. 2005. 